\title{
Effect of Platelet Rich Plasma on an Experimental Rat Model of Adriamycin Induced Chronic Kidney Disease
}

\author{
ISLAM I. HEGAB, M.D.*; RANIA N. ABD-ELLATIF, M.D.** and MARWA M. ATEF, M.D.** \\ The Departments of Physiology* and Biochemistry**, Faculty of Medicine, Tanta University, Egypt
}

\begin{abstract}
Background: Chronic kidney disease (CKD) is a worldwide health problem with increased mortality and morbidity. Currently, there is no effective protective therapy against CKD- induced renal damage with its sequel of end stage renal disease. Platelet-rich plasma (PRP) has a progressively gained consideration in wound healing, repair/regeneration of damaged tissues and conservation of organ function.

Aim of Study: This current study was planned to evaluate the possible protective effect of PRP treatment on a rat model of Adriamycin (ADR)-induced CKD.

Material and Methods: Sixty male albino rats were included; 30 were used for PRP preparation and the other 30, were randomly categorized into three equal groups of ten rat each: Normal control group, ADR group and PRP treated ADR group. At the end of experimental regimen (6 weeks), $24 \mathrm{~h}$ urine samples were collected for measuring $24 \mathrm{~h}$ urinary protein excretion and creatinine clearance $(\mathrm{Cr} \mathrm{Cl})$, then rats were decapitated and blood samples were collected for measuring serum albumin, triglycerides and cholesterol along with serum creatinine and blood urea nitrogen (BUN). Renal tissue samples were harvested and used for determination of renal level and mRNA expression of nephrin along with levels of hepatocyte growth factor (HGF), malondialdehyde (MDA), super oxide dismutase (SOD) activity, tumor necrosis factor alpha (TNF- $\alpha$ ), interleukin $1-\beta$ (IL-1 $\beta$ ), and transforming growth factor $1 \beta$ (TGF $1 \beta$ ) in renal homogenates.
\end{abstract}

Results: Platelet rich plasma treatment improved ADR induced proteinuria, hyperlipidemia and renal dysfunction, which was accompanied by parallel upregulation of renal nephrin and inhanced levels of HGF and SOD activity, whereas the increased levels of TNF- $\alpha$, IL- $1 \beta$ and TGF $1 \beta$ were attenuated.

Conclusion: Platelet rich plasma could potentially protect against ADR induced CKD by alleviating its associated proteinuria, hyperlipidemia and the altered oxidative stress, inflammatory and fibrogenic responses.

Key Words: Platelet rich plasma-Adriamycin-Chronic kidney disease - Proteinuria.

Correspondence to: Dr. Islam I. Hegab, E-Mail: (dr.islamhegab@gmail.com).

\section{Introduction}

CHRONIC kidney disease is a worldwide health problem, that occurs as a result of exposure to wide range of deleterious agents as environmental toxins and drugs [1], with diabetes, hypertension and obesity were considered to be the main underlying risk factors [2]. Most types of CKD are characterized by a progressive loss of kidney function, reduced glomerular filtration and chronic massive proteinuria [3], with vicious cycle of nephron damage, progressive glomerulo-sclerosis, tubuleinterstitial fibrosis, and finally end stage renal disease [4]. The alarming increase in chronic and end stage renal disease paid the attention to identify the possible mechanisms that perpetuate and exacerbate renal dysfunction; to develop strategies to prevent and/or modulate them [5] .

Adriamycin (ADR) is an anthracycline-based anticancer drug whose therapeutic use has been limited due to the incidence of cardiac, renal, hematological and testicular toxicities [6]. Adriamycin-induced nephropathy is a classic well accepted rat model of CKD, characterized by focal glomerulo-sclerosis leading to chronic proteinuria and renal failure [7]. The exact mechanisms of renal injury induced by ADR are not yet fully elucidated [8,9]. Studies reported that ADR-induced CKD is associated with hypoalbuminemia, dyslipidemia and proteinuria [10]. Adriamycin caused a wide effacement of podocyte foot processes disrupting the integrity of slit diaphragms (SD) with subsequent proteinuria, focal segmental glomerulosclerosis and tubule-interstitial damage [11]. Nephrin is one of the most important podocyte-associated proteins, playing a key role in maintaining the integrity of SD, keeping the constructional and 
functional properties of the glomerular filtration barrier [12]. Defects in nephrin expression had been identified as a leading cause of several inherited and acquired forms of proteinuria [13].

It had been well documented that proteinuria is not only a marker for the progression of CKD, but also acts as a pathogenic mediator that promotes tubular injury and interstitial fibrosis $[\mathbf{1 4 , 1 5}$. In addition, oxidative stress, inflammation, and endothelial/epithelial mesenchymal transition were also regarded as key mediators of renal injury and fibrosis with a sequel of progressive loss of renal function in CKD [16,17]. Consequently, factors having anti-proteinuric, antioxidant and antiinflammatory effects may have a special interest in ameliorating CKD disease progression.

Platelet rich plasma is recently known for its powerful healing properties and an up-growing role in regenerative medicine [18]. It is an autologous derivative of whole blood rich in active growth factors (GFs). Its powerful therapeutic potentials may be attributed to its ability to deliver great variety of biologically active GFs to the site of injury with its simplicity, effectiveness, safety, and constant availability [19]. Platelets contain three types of granules containing many of GFs and bioactive molecules including; hepatocyte growth factor (HGF); insulin-like growth factor-I (IGFI), epidermal growth factor adenosine diphosphate (ADP) and tri-phosphate (ATP), among others [20] These factors were shown to enhance renal tubular cell regeneration and repair kidney structure and function after damage in various experimental renal models [21]. Platelet rich plasma have underscored beneficial effects in different experimental models of acute and chronic renal injury; which could be attributed to its regenerative, antioxidant and anti-inflammatory characteristics $[22,23]$. Thereby, it could be anticipated that the administration of PRP as a natural cocktail of many GFs and bioactive molecules may protect against or delay the disease progression in ADR induced CKD.

Due to increased incidence of CKD and numerous side effects of chemical drugs usage, it is necessary to look for a cheap, safer and highly effective therapy. Irrespective of the role of PRP in regenerative and healing medicine, its influence on ADR-induced CKD had not been previously explored. Therefore, this study was carried out to evaluate the impact of PRP on ADR-induced CKD model in rats, with shedding the light on the possible mechanisms underlying its actions.

\section{Material and Methods}

\section{Chemicals and reagents:}

The ADR in the form of (ADR hydrochloride) vial was purchased from EIMC United Pharmaceuticals, Egypt. All other chemical reagents were of high purity and analytical grade and were obtained from (Sigma, USA), unless described otherwise.

\section{Platelets rich plasma preparation:}

Thirty male albino rats were used as blood donors, which were anesthetized with ether, sacrificed and blood was collected on sodium citrate anticoagulant solution (9 parts of blood : 1 part of sodium citrate), then centrifuged at $1000 \mathrm{rpm}$ for $15 \mathrm{~min}$,after which plasma was collected and centrifuged at $3000 \mathrm{rpm}$ for $10 \mathrm{~min}$ to get PRP. Then PRP concentrate was dissolved in phosphate buffer saline (PBS) (1:1) [24,25]. Platelets were counted and platelet number was ranged from 1000000/ to $1800000 /$

\section{Study design and animal grouping:}

This study was conducted from April 2018 to August 2018, and all procedures were performed according to the guidelines of the Research Ethical Committee of Tanta Faculty of Medicine. Sixty adult male albino rats weighing 200-250g were used in this experiment. Proper acclimatization for one week in the animal house with, $12 \mathrm{~h}$ lighting cycle and $24 \pm 2{ }^{\circ} \mathrm{C}$ temperature. The rats were housed five per cage, had free access to standard rodent chow and water. Randomly thirty male albino rats from them were used in preparing PRP as described previously [24,25], while the other thirty rats were categorized into three equal groups of 10 rats each:

- Normal control group: This rat group received a single intravenous injection (tail vein) of $0.5 \mathrm{ml}$ of $0.9 \%$ saline solution.

- Adriamycin group (ADR): Rats of this group received a single intravenous injection of ADR (tail vein) at a dose of $(6 \mathrm{mg} / \mathrm{kg}$ body weight, dissolved in $0.5 \mathrm{ml}$ of $0.9 \%$ saline solution), to induce chronic kidney disease [26]

- PRP treated ADR group (PRP-ADR): This rat group injected with a single intravenous injection of ADR as described above, then received intra peritoneal injection of PRP, at dose of $1 \mathrm{ml} / \mathrm{kg}$, twice/week for 6 weeks [23], starting from the first day of ADR injection.

\section{Collection of urine samples:}

At the end of the study period (6 weeks), rats in each group were individually housed in metabolic 
cage for $24 \mathrm{~h}$ urine collection. Total urine volume was measured; one $\mathrm{ml}$ was collected from the $24 \mathrm{~h}$ urine sample, and used for measurement of $24 \mathrm{~h}$ urinary protein excretion and $\mathrm{Cr} \mathrm{Cl}$.

\section{Blood and tissue sampling:}

All rats were anesthetized with ether, then sacrificed and blood samples were collected and centrifuged at $3000 \mathrm{xg}$ for $15 \mathrm{~min}$, and stored at $-20^{\circ} \mathrm{C}$ till usage for determination of serum biochemical parameters. Then kidneys of each rat were gently dissected, weighed, washed with ice cold saline, then they were homogenized as $10 \%$ $(\mathrm{w} / \mathrm{v})$ in $50 \mathrm{mM}$ phosphate buffer $(\mathrm{pH} 7.4)$ and centrifuged at $5000 \mathrm{xg}$ for $20 \mathrm{~min}$ at $4{ }^{\circ} \mathrm{C}$. The resultant supernatant was then divided into aliquots and kept frozen at $-80^{\circ} \mathrm{C}$ until used for biochemical analysis. Total protein content was measured in renal tissue homogenates using the Lowry method as described previously [27].

Determination of 24 h urinary protein excretion and serum albumin, triglyceride and cholesterol:

Measurement of total urinary protein concentration was assayed using the method of Bradford [28]. Serum albumin was determined according to the method described by Doumas and Watson [29], while serum triglycerides and cholesterol were assayed using colorimetric kits supplied by (Biomed Diagnostics. EGY-Chem., Egypt).

\section{Biochemical assessment of renal function:}

Serum and urinary creatinine were measured using colorimetric kits supplied by (Diamond Diagnostics, Egypt). Blood urea nitrogen was determined based on urease-colorimetric method using spectrum diagnostics kits. Creatinine clearance, as index for glomerular filtration rate was measured according to the standard equation:

$\mathrm{Cr} \mathrm{Cl}(\mathrm{ml} / \mathrm{min})=$ Urine creatinine $(\mathrm{mg} / \mathrm{dl}) \mathrm{x}$ Urine output ( $\mathrm{ml} / 24 \mathrm{hrs}) /$ Serum creatinine) $\mathrm{mg} / \mathrm{dl}$ ) $\mathrm{x} 1440(\mathrm{~min})$ [30]

\section{Assessment of renal nephrin and HGF levels:}

Levels of renal nephrin contents were quantified in kidney homogenate with ELISA kits (Cusabio biotech CO., Ltd, Wuhan, China), while renal HGF was determined using ELISA supplied by (Sunred Biological Technology, China),following the manufacturer's protocol.

Assesment of renal redox status, TNF- $\alpha, I L I$ $\beta$ and TGF $\beta$ :

Malondialdehyde and SOD activity levels were determined according to the methods described by Ohkawa et al. [31] and Misra and Fridovich [32], respectively. Meanwhile, renal assay for TNF- $\alpha$, IL $1 \beta$ and TGF- $\beta$ were performed using their respective ELISA kits supplied by (RayBiotech, Inc., USA), (abcam, MA, USA) and (MyBiosource USA), respectively. All procedures were performed according to the manufacturers' instructions.

Assessment of nephrin gene expression using quantitative real Time PCR:

Isolation of total RNA from kidney samples was performed using Gene JET RNA Purification Kit (Thermo Scientific, \# K0731, USA). Total RNA (5 then reverse transcribed producing cDNA using Revert Aid H Minus Reverse Transcriptase (Thermo Scientific, \#EP0451, USA). The cDNA was used as a template to determine the relative expression of nephrin genes using Step One Plus real time PCR system (Applied Biosystem, USA). The PCR primer sequence was as follow: (Forward: 5'-TGTGAGGATCCGAGGGG AAT-3', Reverse: 5'-GGAAACGGGTGTTG TGAAGC-3') the housekeeping gene $\beta$-actin (Forward: 5 '-TATCCTGGCCTCACTGTCCA-3', Reverse: 5 '-AACGCAGCTCAGTAACAGTC-3'). The relative gene expression was calculated using 2- ${ }^{-C t}$ method [33].

\section{Statistical analysis:}

Statistical analysis was carried out using the mean and standard deviation (SD) using SPSS for windows (Version 21.0). One-way analysis of variance (ANOVA) was used for multiple comparison to evaluate the statistical significance between experimental groups with Tukey post hoc test analysis, $p$-value $<0.05$ was considered significant. Correlation between variables was evaluated using Pearson's correlation coefficient with level of significance $<0.05$.

\section{Results}

Effect of PRP treatment on urinary 24 h urinary protein excretion and serum albumin, triglycerides and cholesterol levels:

As shown in Table (1), rats in the ADR group exhibited significantly higher levels of 24h urinary protein excretion, serum triglycerides and cholesterol, which was associated with significantly lower serum albumin levels, when compared with the normal control group $(p<0.05)$. Concomitant administration of PRP with ADR significantly reduced the levels of $24 \mathrm{~h}$ urinary protein excretion, serum triglycerides and cholesterol, whereas it significantly increased serum albumin levels in rats of the PRP-ADR group versus the ADR group $(p<0.05)$. 
Effects of PRP treatment on renal function related parameters:

As compiled in Table (2), serum creatinine and BUN were significantly higher, whereas $\mathrm{Cr} \mathrm{Cl}$ was significantly lower in rats of ADR group compared to normal control group $(p<0.05)$. PRP administration significantly decreased both serum creatinine and BUN, while significantly increased $\mathrm{Cr} \mathrm{Cl}$, in the PRP-ADR group compared to the ADR group. $(p \leq 0.05)$.

Effect of PRP on renal oxidative stress markers, inflammatory cytokines and TGF $\beta-1$ :

Compared with the normal control group, renal MDA levels were significantly higher, whereas renal SOD activity levels were significantly lower in the ADR group $(p \leq 0.05)$. On the other hand, PRP administration resulted in a significant decrease in MDA levels along with a significant increase in SOD activity levels in the rats of PRP-ADR group versus the ADR group $(p \leq 0.05)$. (Table 3$)$.

In addition, results of Table (3) also elucidated significantly increased levels of TNF- $\alpha$, IL $1 \beta$ and TGF $\beta-1$ in renal homogenates obtained from ADR group compared to normal control one, whereas these levels were significantly decreased in the rats of PRP-ADR group compared to ADR group $(p \leq 0.05)$.

Effect of PRP on levels of nephrin and HGF in renal tissues of experimental rats:

As depicted in Figs. (1,2), ADR administration significantly decreased renal nephrin level and mRNA expression which was associated with lower levels of renal HGF in rats of ADR group compared with the normal control group $(p \leq 0.05)$. Meanwhile, these values were significantly increased upon PRP administration in rats of PRP-ADR group compared with the ADR group $(p \leq 0.05)$.

Pearson correlation analysis of HGF with $24 \mathrm{~h}$ urinary protein excretion and renal biochemical markers in different studied groups:

Results of Table (4) revealed that HGF presented a significant positive correlation $(p<0.05)$ with renal nephrin level whereas, a statistically significant negative correlation $(p<0.05)$ was found between renal HGF level in one hand and MDA, TNF $\alpha$ and TGF- $\beta 1$ levels on the other hand $(p<0.05)$
Table (1): Effect of PRP treatment on 24h urinary protein excretion and serum albumin, triglyceride and cholesterol in experimental rats.

\begin{tabular}{lcll}
\hline Pararmeters / groups & $\begin{array}{c}\text { Normal } \\
\text { control } \\
\text { group }\end{array}$ & $\begin{array}{c}\text { ADR } \\
\text { group }\end{array}$ & $\begin{array}{c}\text { PRP-ADR } \\
\text { group }\end{array}$ \\
\hline $\begin{array}{l}\text { Urinary protein excretion } \\
(\mathrm{mg} / 24-\mathrm{h} \text { urine) }\end{array}$ & $3.6 \pm 1.25$ & $89 \pm 21.43 \mathbf{a}$ & $21 \pm 8.78 \mathbf{a b}$ \\
Serum albumin (g/dl) & $2.44 \pm 0.38$ & $1.36 \pm 0.47 \mathbf{a}$ & $2.28 \pm 0.51 \mathbf{b}$ \\
Serum triglycerides (mg/dl) & $64 \pm 9.25$ & $421 \pm 101.67 \mathbf{a}$ & $190 \pm 76.53$ ab \\
Serum cholesterol (mg/dl) & $75 \pm 15.39$ & $435 \pm 96.74 \mathbf{a}$ & $210 \pm 83 \mathbf{a b}$ \\
\hline
\end{tabular}

- Data are mean \pm standard deviation of a group of 10 rats. Statistical analysis is carried out using one-way ANOVA with Tukey's post hoc test using SPSS program.

a Significant difference vs. normal control group $(p<0.05)$

b Significant difference vs. ADR group $(p<0.05)$.

Table (2): Effect of PRP treatment on renal function related parameters in experimental rats.

\begin{tabular}{lclc}
\hline Pararmeters / groups & $\begin{array}{c}\text { Normal } \\
\text { control } \\
\text { group }\end{array}$ & $\begin{array}{c}\text { ADR } \\
\text { group }\end{array}$ & $\begin{array}{c}\text { PRP+ADR } \\
\text { group }\end{array}$ \\
\hline $\begin{array}{c}\text { serum creatinine } \\
(\mathrm{mg} / \mathrm{dl})\end{array}$ & $0.4833 \pm 0.12$ & $1.17 \pm 0.35^{\mathbf{a}}$ & $0.633 \pm 0.17 \mathbf{b}$ \\
$\begin{array}{c}\text { Blood urea nitrogen } \\
(\mathrm{mg} / \mathrm{dl})\end{array}$ & $24 \pm 9.6$ & $83 \pm 17.93 \mathbf{a}$ & $31 \pm 11.75 \mathbf{b}$ \\
$\begin{array}{c}\text { Creatinine clearance } \\
(\mathrm{ml} / \mathrm{min})\end{array}$ & $1.194 \pm 0.47$ & $0.631 \pm 0.13 \mathbf{a}$ & $0.975 \pm 0.29 \mathbf{a b}$ \\
\hline
\end{tabular}

- Data are mean \pm standard deviation of a group of 10 rats. Statistical analysis is carried out using one-way ANOVA with Tukey's post hoc test using SPSS program.

a Significant difference vs. normal control group $(p<0.05)$

b Significant difference vs. ADR group $(p<0.05)$.

Table (3): Effect of PRP treatment on renal oxidative stress markers, inflammatory cytokines and TGF $\beta$ in experimental rats.

\begin{tabular}{cccc}
\hline Pararmeters / groups & $\begin{array}{c}\text { Normal } \\
\text { control } \\
\text { group }\end{array}$ & $\begin{array}{c}\text { ADR } \\
\text { group }\end{array}$ & $\begin{array}{c}\text { PRP+ADR } \\
\text { group }\end{array}$ \\
\hline $\begin{array}{c}\text { Renal MDA level } \\
\text { (nmol/mg protein) }\end{array}$ & $0.24 \pm 0.06$ & $0.78 \pm 0.15^{\mathbf{a}}$ & $0.33 \pm 0.08^{\mathbf{a}}$ \\
$\begin{array}{c}\text { Renal SOD activity } \\
\text { (units/mg protein) }\end{array}$ & $7.38 \pm 1.12$ & $3.47 \pm 0.76^{\mathbf{a}}$ & $6.95 \pm 0.93 \mathbf{b}$ \\
$\begin{array}{c}\text { Renal TNF- } \alpha \text { level } \\
\text { (pg/mg protein) }\end{array}$ & $13 \pm 4.63$ & $48 \pm 9.57^{\mathbf{a}}$ & $17.83 \pm 6.39 \mathbf{b}$ \\
$\begin{array}{l}\text { IL } 1 \mathrm{~B} \text { (pg/mg protein) } \\
\text { TGF } \beta \text { 1 } \\
\quad(\mathrm{pg} / \mathrm{mg} \text { protein) }\end{array}$ & $25 \pm 6.89$ & $87 \pm 20.33^{\mathbf{a}}$ & $41 \pm 9.45^{\mathbf{a b}}$ \\
\hline
\end{tabular}

- Data are mean \pm standard deviation of a group of 10 rats.

MDA : Malondialdehyde.

SOD : Superoxide dismutase.

TNF- $\alpha$ : Tumor necrosis factor- $\alpha$.

TGF $\beta$ 1: transforming factor $\beta 1$.

- Statistical analysis is carried out using one-way ANOVA with

Tukey's post hoc test using SPSS program.

a Significant difference vs. normal control group $(p<0.05)$

b Significant difference vs. ADR group $(p<0.05)$. 
Table (4): Correlation analysis of renal HGF with 24h urinary protein excretion and renal biochemical parameters in different studied groups.

\begin{tabular}{ll}
\hline & Renal HGF level \\
\hline 24 h urinary protein excretion & $r=-0.714^{*}$ \\
Nephrin & $r=0.762^{*}$ \\
MDA & $r=-0.611 *$ \\
SOD activity & $r=0.218$ \\
TNF a & $r=-0.731 *$ \\
IL-1 p & $r=-0.318$ \\
TGF- $\beta$ 1 & $r=-0.647 *$ \\
\hline
\end{tabular}

Correlation study was performed using Pearson correlation.

* Significance was considered at level of $p<0.05$.
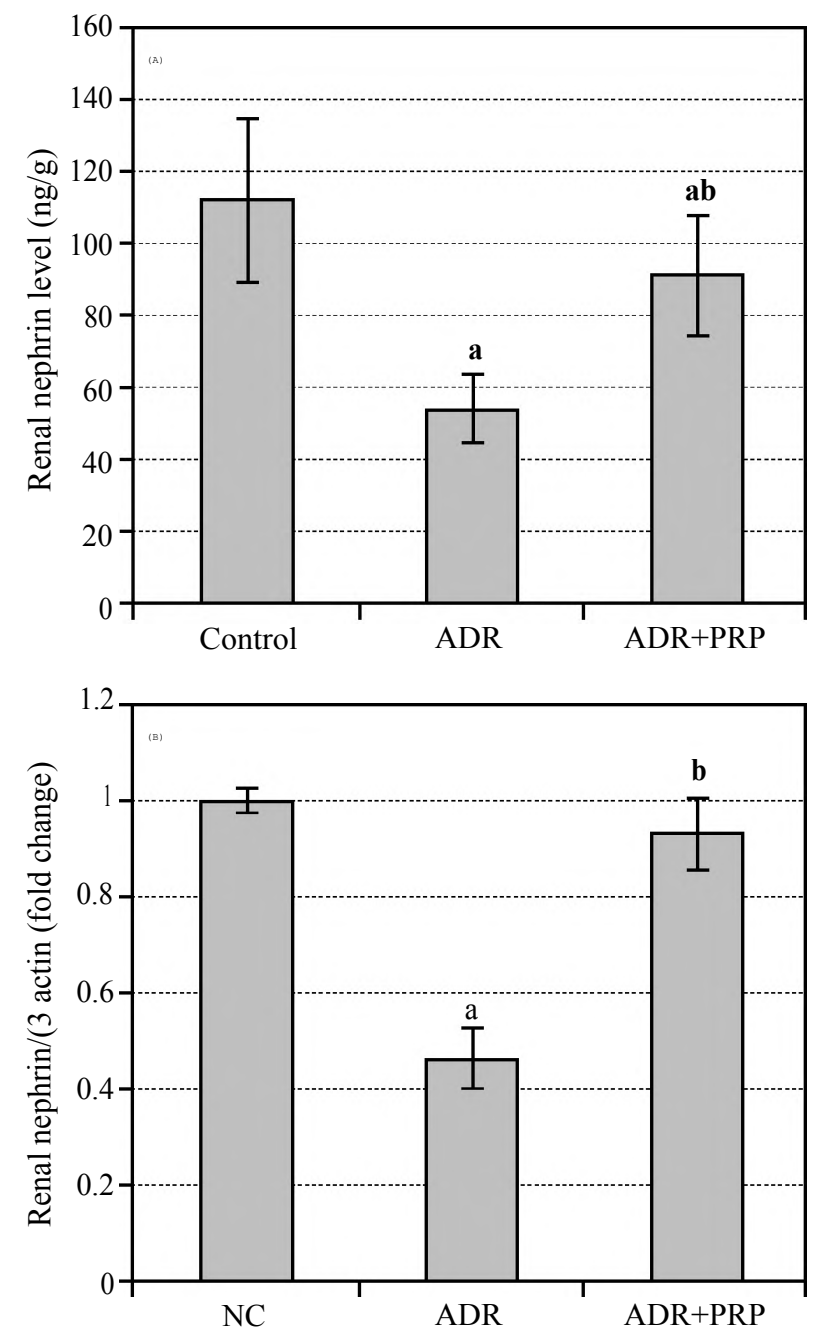

Fig. (1): Effect of PRP on renal nephrin level (1A) and nephrin expression $(1 \mathrm{~B})$ in experimental rats.

NC : Normal control group.

ADR: ADR treated group.

ADR+PRP: PRP treated ADR group.

- Statistical analysis is carried out using one-way ANOVA with

Tukey's post hoc test using SPSS program.

a Significant difference vs. control group $(p<0.05)$.

b Significant difference vs. ADR group $(p<0.05)$.

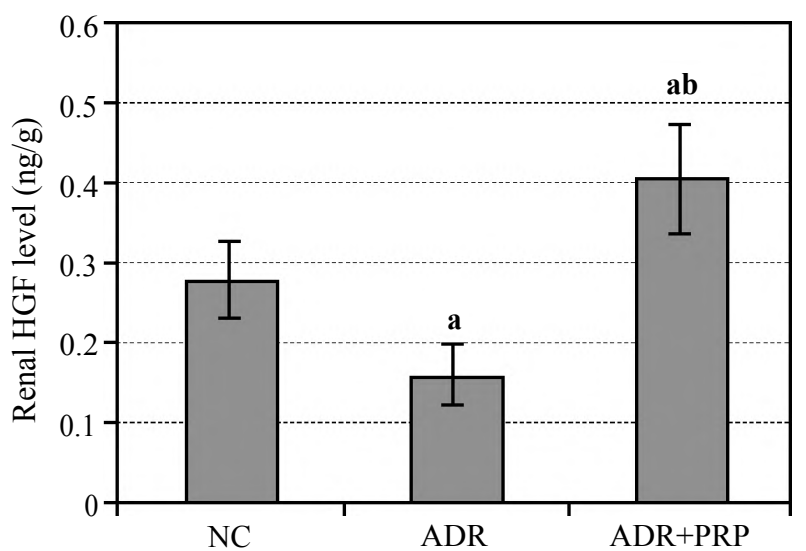

Fig. (2): Effect of PRP on renal HGF level in experimental rats.

NC : Normal control group.

ADR: ADR treated group.

ADR+PRP: PRP treated ADR group.

- Statistical analysis is carried out using one-way ANOVA with

Tukey's post hoc test using SPSS program.

a Significant difference vs. control group $(p<0.05)$.

b Significant difference vs. ADR group $(p<0.05)$.

\section{Discussion}

The major findings of this current study can be summarized as follows: (i) Treatment with ADR caused deterioration of the renal function and serum biomarkers which was accompanied by exacerbated renal oxidative stress, inflammatory and fibrogenic responses. (b) PRP could protect against ADR induced renal pathology by several mechanisms as proposed in this current study.

The results obtained herein showed that injection of ADR was associated with proteinuria, hypoalbuminemia and hyperlipidemia which were accompanied by significant reduction in renal nephrin levels and mRNA expression in ADR group compared to the control one. Similar results were recorded by earlier studies [10,34]

The ADR induced proteinuria could be as a result of its direct toxicity through releasing free radicals that damage the glomerular structure with loss of nephrin [35] ; or may be indirectly through the released inflammatory cytokines which inhibit the activity of the nephrin gene promoter [36], this in turn disturb the integrity of SD with sustained proteinuria [37]. The resultant proteinuria and its sequel of hypoalbuminemia and decreased serum oncotic pressure leads to stimulation of the hepatic synthesis of triglycerides and cholesterol with subsequent hyperlipidemia [38]. Moreover, Hong et al. [39] emphasized that ADR induced hyperlipidemia could be attributed to the inhibition of carnitine palmitoyl transferase system and the lowered level of cytochrome P450 which depress 
cholesterol $7 \alpha$-hydroxylase activities, the key enzyme in conversion of cholesterol to bile acids.

In addition, our investigations showed that proteinuria was associated with renal function impairment in ADR-treated rats, as indicated by significantly increased levels of serum creatinine, BUN with decreased $\mathrm{Cr} \mathrm{Cl}$ in the ADR group compared with the normal control group, which was in harmony with previous studies [25,40-42] This could be attributed to either; direct ADR toxicity mediated via tubular cell chemokine release and oxidant injury [11]; or indirectly through ADR induced proteinuria which triggers tubular cell activation and injury with attraction of interstitial inflammatory cytokines resulting in tubular interstitial damage with gradual loss of renal function $[43,44]$

From the over mentioned data, the role of oxidative stress and inflammation in ADR pathophysiology could not be ruled out. In accordance, our results showed an imbalance of redox status as revealed by significantly increased levels of MDA and decreased SOD levels, which was associated with increased inflammatory cytokines; TNF $\alpha$ and IL-1 $\beta$ in kidney tissues of ADR-treated rats compared to control ones. These findings came in line with previous studies $[\mathbf{4 5 , 4 6 ]}$

Oxidative stress may cause direct toxicity to the cells, causing damage to DNA, protein, and lipids or may indirectly trigger the release of chemokine from injured renal cells with subsequent renal infiltration or activation of macrophages and $\mathrm{T}$ cells $[4 \mathbf{4 7 , 4 8}]$. Activated or recruited macrophages and $\mathrm{T}$ cells secrete inflammatory cytokines as TNF $\alpha$ and IL- $1 \beta$ which could induce mesangial expansion, podocyte injury, and endothelial damage, instigating glomerulo-sclerosis and interstitial fibrosis which mostly lead to renal failure $[11,46]$

Several lines of evidence emphasized the pivotal role of TGF- $\beta 1$ in the progression of fibrosis in CKD [49] (Chen et al., 2018). In accordance, this current study elucidated a significantly increased renal level of TGF- $\beta 1$ in ADR group compared to control one, which agree previous studies [50,51] The pro fibrotic TGF- $\beta 1$ had been involved in the synthesis and deposition of extracellular matrix (ECM) together with stimulation of the pro inflammatory and pro fibrotic mediators promoting the ADR induced tubule-interstitial fibrosis [52]. Moreover, it could down regulate the expression of nephrin, exacerbating the proteinuric injury and its associated pathology [53]
The second major objective in this current work was to investigate the impact of PRP on ADR induced renal pathology. The present study demonstrated a protective role for PRP against ADRinduced CKD as evidenced by significantly improved $24 \mathrm{~h}$ urinary protein excretion ,serum albumin and lipids along with decreased levels of serum creatinine and BUN, whereas $\mathrm{Cr} C l$ was significantly increased in the PRP-ADR treated group compared to the ADR-treated group. These protective potentials of PRP were associated with parallel accentuation of renal nephrin levels and expression with reduction in renal oxidative and inflammatory markers with fibrogenic cytokine; TGF- $\beta 1$.

The effect of PRP on proteinuria may be mediated mostly, via its released HGF which is a multifunctional pleiotropic growth factor that was shown to abrogate CKD and many podocyte injurybased proteinuric renal diseases [54]. Moreover, stimulation of renal HGF was recorded to ameliorate proteinuria, podocytopenia and glomerulosclerosis in nephrotic models [55-57]. Thus, renal level of HGF was estimated in this current study; to evaluate its role in mediating the anti- proteinuric effect of PRP in this rat model. Noteworthy, our results showed a significant decreased level of renal HGF upon ADR injection, which was significantly increased upon PRP injection. Similar results were recorded previously $[23,57]$. The increased renal levels of HGF by PRP could be attributed to its own content of this growth factor, beside its stimulation to HGF production; possibly via its ability to increase the intracellular cyclic adenosine monophosphate (cAMP) in the kidney $[20,23]$. HGF production in cultured cells was shown to be induced by cAMP activating agents and growth factors whereas, it is inhibited by TGF- $\beta$ [58].

Hepatocyte growth factor could ameliorate proteinuria through several proposed mechanisms including; first: Its ability to directly target the podocytes, preventing their foot process effacement, stabilizing nephrin and protecting the integrity of the SD [59]; second: Its suppression to TGF- $\beta 1$ production in mesangial cells [60] which may reverse its down regulation to nephrin expression [52] ; third: Its effect on inflammatory cytokines [61] which may counteract their inhibition to the transcriptional activity of nephrin promoters [36]; lastly: Its anti-apoptotic effect which could protect against ADR induced podocyte apoptosis [56]. In accordance to these findings, our results revealed that the renal HGF level was positively correlated with renal nephrin levels, whereas, negatively correlated with $24 \mathrm{~h}$ urinary excretion along with 
MDA, TNF $\alpha$ and TGF- $\beta 1$ levels, the main promoters of proteinuria in this rat model, supporting our hypothesis.

As a consequence of reduction of proteinuria upon PRP treatment, there was also a significant improvement in serum albumin and marked reduction in serum triglycerides and cholesterol. Consistently, agents targeting proteinuria was shown to be associated with improvement of hyperlipidemia with its sequel of cardiovascular risk $[\mathbf{6 2 , 6 3}]$ the main leading cause of mortality in CKD [64] Moreover, this attenuation of proteinuria could protect against its associated tubular injury and interstitial fibrosis which may have a role in mitigating ADR induced renal dysfunction. In accordance, a variety of approaches targeting proteinuria were reported to improve the renal function in CKD models [40]

A part from the anti-proteinuric effect of PRP mediated via HGF, its other released GFs and bioactive molecules may contribute in mitigating the ADR induced renal pathology and dysfunction in this rat model. For example; IGF-I was recorded to preserve glomerular filtration rate, renal blood flow, and renal excretory function in CKD, possibly via reducing renal arteriolar resistance and increasing the glomerular ultrafiltration coefficient, which could be mediated via increasing the nitric oxide production $[\mathbf{6 5 , 6 6 ]}$. Epidermal growth factor could promote epithelization, accelerate the healing process and boost DNA synthesis in regenerating renal tubules [67]. Hepatocyte growth factor was shown to ameliorate CKD; also via suppressing tubular epithelial to mesenchymal transition, apoptosis and inflammation [68]. Moreover, the adenosine produced by adenine nucleotides degradation could mediate tissue protection and repair by increasing oxygen supply, suppressing inflammation, and promoting angiogenesis [69].

In addition, the antioxidant potentials of PRP as recorded herein, may also explain its renoprotective effect in this rat model, which came in parallel with previous studies $[\mathbf{2 0 , 2 3}$. Its antioxidant capacity could be attributed to its ability to induce the expression of SOD enzyme and the nuclear factor-erythroid-2-related factor 2, the master regulator of anti-oxidant enzymes expression [70,71], which in turn could dampen the ADR induced oxidative stress and its associated pathology.

Moreover, the present work demonstrated the ability of PRP to suppress the released inflammatory cytokines, which could play a role in ameliorating ADR induced nephropathy. Consistently, the anti- inflammatory agents were recorded to reduce proteinuria via restoring the nephrin expression [72] and could ameliorate the tubule-interstitial damage, decreasing the disease progression in ADR induced nephropathy models [73]. The anti-inflammatory effect of PRP could be attributed to its ability to suppress the translocation of nuclear factor $\kappa \mathrm{B}$ and its downstream molecules, TNF $\alpha[\mathbf{7 4 , 7 5}]$, or may be due to its capability to increase the intracellular expression of the anti-inflammatory mediators (IL-4, IL-10, and IL-13) and to decrease the IL-1 $\beta$-mediated catabolic effects [76].

Our investigations also declared a significantly reduced levels of TGF- $\beta 1$ upon PRP treatment, signifying its anti-fibrotic potentials which was supported previously [23]. This effect may be due to its content of HGF and its ability to increase cAMP and HGF levels [20,23], which were documented for their ability to down regulate the TGF$\beta$ and the other fibrosis-related genes as $\alpha$-SMA, collagens and fibronectin [77,78]. Moreover, the anti-inflammatory and anti-apoptotic effects of PRP together with its suppression to ECM accumulation may contribute to its anti- fibrotic potentials as recorded previously [21,79].

\section{Conclusion:}

From the results of this current study, PRP exhibited a protective effect against ADR-induced CKD, which could be attributed to its antiproteinuric, anti-hyperlipidemic, antioxidant, antiinflammatory and anti-fibrotic potentials as recorded herein in this current study. Thus, PRP may play a role in clinical innovations for protection against CKD. The efficacy and safety of PRP for treating CKD and its underlying mechanisms need further studies.

\section{Conflict of interest:}

The authors declare that they have no conflict of interest.

\section{References}

1- PERAZELlA M.A.: Renal Vulnerability to Drug Toxicity. Clin. J. Am. Soc. Nephrol., 4 (7): 1275-1283, 2009.

2- MARIC-BILKAN C .: Obesity and Diabetic Kidney disease Med. Clin. North Am., 97 (1): 59-74, 2013.

3- DING Z.H., XU L.M., WANG S.Z., KOU J.Q., XU Y.L., CHEN C.X., et al.: Ameliorating Adriamycin-Induced Chronic Kidney Disease in Rats by Orally Administrated Cardiotoxin from Naja naja atra Venom. Evid. Based Complement Alternat. Med., 621756, 2014.

4- TANADA Y., OKUDA J., KATO T., MINAMINO-MUTA E., MURATA I., SOGA T., et al.: The metabolic profile of a rat model of chronic kidney disease, Peer J., 5: e3352, 2017. 
5- LERMAN L.O. and CHADE A.R.: Angiogenesis in the kidney: A new therapeutic target. Curr. Opin. Nephrol. Hypertens., 18 (2): 160-165, 2009.

6- ANISS H.A., SAID M., EL SAYED I.H., ADLY C.: Amelioration of adriamycin-induced cardiotoxicity by Salsola kali aqueous extract is mediated by lowering oxidative stress. Redox Rep., 19 (4): 170-8, 2014.

7- PIPPIN J.W., BRINKKOETTER P.T., CORMACKABOUD F.C., DURVASULA R.V., HAUSER P.V., KOWALEWSKA J., et al.: Inducible rodent models of acquired podocyte diseases. Am. J. Physiol. Renal. Physiol., 296: F213-F229, 2009.

8- TACAR O., SRIAMORNSAK P. and DASS C.R.: Doxorubicin: An update on anticancer molecular action, toxicity and novel drug delivery systems. J. Pharm. Pharmacol., 65: 157-70, 2013.

9- CHATTEЮEE K., ZHANG J., HONBO N. and KARLINER J.S.: Doxorubicin cardiomyopathy. Cardiology, 115: 155-62, 2010.

10-HUSSEIN A.M., ELDOSOKY M., HANDHLE A., ELSEROUGY H., SARHAN M., SOBH M.A., et al.: Effects of long acting erythropoietin analog darbepoetin- $\alpha$ on Adriamycin-induced chronic nephropathy Int. Urol. Nephrol., 48: 287-297, 2016.

11- LEE V.W. and HARRIS D.C.: Adriamycin nephropathy: A model of focal segmental glomerulo-sclerosis. Nephrology (Carlton), 16: 30-8, 2011.

12- WU X., AN P., YE B., SHI X., DANG H. and FU R.: Artemisinin ameliorated proteinuria in rats with adriamycininduced nephropathy through regulating nephrin and podocin expressions. J. Tradit. Chin. Med., 34: 63-8, 2014.

13- DINDA A.K., SINGH L. and SINGH G.: Understanding podocytopathy and its relevance to clinical nephrology. Indian J. Nephrol., 25: 1-7, 2015.

14- ABBATE M., ZOJA C. and REMUZZI G.: How does proteinuria cause progressive renal damage? Journal of the American Society of Nephrology, 17 (11): 2974-2984, 2006.

15- ZANDI-NEJAD K., EDDY A., GLASSOCK R.J. and BRENNER B.M.: "Why is proteinuria an ominous biomarker of progressive kidney disease?" Kidney International, 66 (92): S76- S89, 2004.

16- GUERROT D., DUSSAULE J.C., KAVVADAS P., BOFFA J.J., CHADJICHRISTOS C.E. and CHATZIANTONIOU C.: Progression of renal fibrosis: The underestimated role of endothelial alterations, Fibrogenesis. Tissue Repair, 5: S 15, 2012.

17-MODARESI A., NAFAR M. and SAHRAEI Z.: Oxidative stress in chronic kidney disease. Iran J. Kidney Dis., 9: 165-179, 2015.

18- ALVES R. and GRIMALT R.: A review of platelet-rich plasma: History, biology, mechanism of action, and classification. Skin Appendage Disord., 4: 18-24, 2018.

19- FRECHETTE J. P., MARTINEAU I. and GAGNON G.: "Platelet-rich plasmas: growth factor content and roles in wound healing", Journal of Dental Research, 84 (5): 434-439, 2005.
20- SHOEIB H.M., KESHK W. A., FODA A.M. and ABO EL NOEMAN S E.A.E.: A study on the regenerative effect of platelet-rich plasma on experimentally induced hepatic damage in albino rats. Can. J. Physiol. Pharmacol., 96 (6): 630-636, 2018.

21- SALEM N., HELMI N. and ASSAF N.: Renoprotective effect of platelet-rich plasma on cisplatin-induced nephrotoxicity in rats .Oxidative Medicine and Cellular Longevity, Article ID 9658230, 10 pages, 2018.

22- SOLIMAN A.F., SAIF-ELNASR M. and ABDEL FATTAH S.M.: Platelet-rich plasma ameliorates gamma radiationinduced nephrotoxicity via modulating oxidative stress and apoptosis. Life Sci., 219: 238-247, 2019.

23- KESHK W. A. and ZAHRANB S.M.: Mechanistic role of cAMP and hepatocyte growth factor signaling in thioacetamide-induced nephrotoxicity: Unraveling the role of platelet rich plasma .Biomedicine \& Pharmacotherapy, 109: 1078-1084, 2019.

24- HESAMI Z., JAMSHIDZADEH A., AYATOLLAHI M., GERAMIZADEH B., FARSHAD O. and VAHDATI A.: Effect of platelet-rich plasma on CCl4-induced chronic liver injury in male rats. International Journal of Hepatology, 932930, 2014.

25- LUCARELLI E., BECCHERONI A., DONATI D., SANGIORGI L., CENACCHI A., DEL VENTO A.M., et al.: Platelet-derived growth factors enhance proliferation of human stromal stem cells. Biomaterials, 24 (18): 30953100, 2003.

26- DING Z.H., XU L.M., WANG S.Z., KOU J.Q., XU Y.L., CHEN C.X., et al.: Ameliorating Adriamycin-Induced Chronic Kidney Disease in Rats by Orally Administrated Cardiotoxin from Naja naja atra Venom. Evidence-Based Complementary and Alternative Medicine. Article ID 621756, 10 pages, 2014.

27- LOWRY O.H., Rosenbrough N.J., Farr A.L. and Randall R.J.: Protein measurement with the Folin phenol reagent. J. Biol. Chem., 93: 265-275, 1951.

28- BRADFORD M.M.: A rapid and sensitive method for the quantitation of microgram quantities of protein utilizing the principle of proteindye binding. Anal . Biochem., 72: 248-254, 1976.

29- DOUMAS B. and WATSON W.A. :"Standard measurement of serum albumin with bromocresolgreen". Clin. Chem. Acad. Press, 31: 87-96, 1971.

30- HUSSEIN A.M., MALEK H.A. and SAAD M.A.: Renoprotective effects of aliskiren on adenine-induced tubulointerstitial nephropathy: Possible underlying mechanisms. Can. J. Physiol. Pharmacol.., 94 (8): 829-37, 2016.

31- OHKAWA H., OHISHI N. and YAG I.: Assay for lipid peroxides in animal tissues by thiobarbituric acid reaction. Anal. Biochem., 95 (2): 351-358, 1979.

32- MISRA H.P. and FRIDOVICH I.: The role of superoxide anion in the auto-oxidation of epinephrine and a simple assay for superoxide dismutase. J. Biol. Chem., 247: 3170-3175, 1972.

33- LIVAK K.J. and SCHMITTGEN T.D.: Analysis of relative gene expression data using real-time quantitative PCR and the 2(-Delta Delta C(T)) Method. Methods, 25: 402-408, 2001. 
34- MANSOURI A.E., ASSAREHZADEGANB M.A., DEHBASHIC F.N. and KOOTI W.: Effects of Pravastatin in Adriamycin-Induced Nephropathy in Rats Iranian Journal of Pharmaceutical Research, 17 (4): 1413-1419, 2018.

35- TESAR V., ZIMA T., JIRSA M., CRKOVSKÁ J., STÍPEK S., VERNEROVÁ Z., SERÁKOVÁ M.: Influence of losartan and enalapril on urinary excretion of 8-isoprostane in experimental nephrotic syndrome. Med. Sci. Monit., 8 (2): 69-74, 2002.

36- TAKANO Y., YAMAUCHI K., HAYAKAWA K., HIRAMATSU N., KASAI A. , OKAMURA M., et al.: Transcriptional suppression of nephrin in podocytes by macrophages: Roles of inflammatory cytokines and involvement of the PI3K/Akt pathway. FEBS Lett., 581: 421-426, 2007.

37- FUJIMURA T., YAMAGISHI S., UEDA S, FUKAMI K., SHIBATA R., MATSUMOTO Y., et al.: Administration of pigment epithelium-derived factor (PEDF) reduces proteinuria by suppressing decreased nephrin and increased VEGF expression in the glomeruli of adriamycin-injected rats. Nephrol. Dial. Transplant., 24 (5): 1397-406, 2009.

38- MARSH J.B.: Lipoprotein metabolism in the nephrotic syndrome. Front Biosci., 1 (7): e326-e338, 2002.

39- HONG Y.M., KIM H.S. and YOON H.: Serum lipid and fatty acid profiles in adriamycin-treated rats after administration of L-carnitine. Pediatr. Res., 51: 249-255, 2002.

40- WEI M., HE WM., LU X., NI L., YANG Y.Y., CHEN L., et al.: Decoction Ameliorates Proteinuria and Kidney Injury in Adriamycin-Induced Rat by Blockade of TGF 3 /Smad Signaling. Evidence-Based Complementary and Alternative Medicine, Article ID 5031890, 11 pages, 2016.

41- MOHEBBATI R., SHAFEI M.N., BEHESHTI F. SOUKHTANLOO M., ROSHAN N.M., ANAEIGOUDARI A., et al.: Mixed hydroalcoholic extracts of nigella sativa and curcuma longa improves adriamycin-induced renal injury in rats. Saudi J. Kidney Dis. Transpl., 28 (6): 1270-1281, 2017.

42- DING Z.H., XU L.M., WANG S.Z., KOU J.Q., XU Y.L., CHEN C.X., et al.: Ameliorating Adriamycin-Induced Chronic Kidney Disease in Rats by Orally Administrated Cardiotoxin from Naja naja atra Venom. Evid Based Complement. Alternat. Med., 621756, 2014.

43- KRAMER A.B., VAN TIMMEREN M.M., SCHUURS T.A., VAIDYA V.S., BONVENTRE J.V., VAN GOOR H. and NAVIS G.: Reduction of proteinuria in adriamycininduced nephropathy is associated with reduction of renal kidney injury molecule (Kim-1) over time. Am. J. Physiol. Renal. Physiol., 296 (5): 1136-1145, 2009.

44- SEAN EARDLEY K. and COCKWELL P.: Macrophages and progressive tubulointerstitial disease. Kidney Int., 68: 437-455, 2005.

45- CAO Q., WANG Y., ZHENG D., SUN Y., WANG Y., LEE VW., et al.: "IL-10/TGF- $\beta$-modified macrophages induce regulatory $\mathrm{T}$ cells and protect against adriamycin nephrosis", Journal of the American Society of Nephrology, 21 (6): 933-942, 2010.

46- SONG I.H., JUNG K.J., LEE T J., KIM J.Y., SUNG E.G., BAE Y.C. and PARK Y.H.: Mesenchymal stem cells attenuate adriamycin-induced nephropathy by diminishing oxidative stress and inflammation via downregulation of the NF-kB. Nephrology (Carlton), 23 (5): 483-492, 2018.
47- WANG Y., WANG Y., CAO Q., ZHENG G., LEE V.W., ZHENG D., et al.: By homing to the kidney, activated macrophages potently exacerbate renal injury. Am. J. Pathol.; 172 (6): 1491-1499, 2008.

48- ASCON M., ASCON D.B., LIU M., CHEADLE C., SARKAR C., RACUSEN L., et al.: Renal ischemiareperfusion leads to long term infiltration of activated and effector-memory T lymphocytes. Kidney Int., 75 (5): 526-35, 2009

49- CHEN L., YANG T., LU D.W., ZHAO H., FENG Y.L., CHEN H., et al.: Central role of dysregulation of TGF 3 /Smad in CKD progression and potential targets of its treatment. Biomed Pharmacother., 101: 670-681, 2018.

50- VERRECCHIA F. and MAUVIEL A.: "Transforming growth factor- $\beta$ signaling through the Smad pathway: Role in extracellular matrix gene expression and regulation", Journal of Investigative Dermatology, 118 (2): 211-215, 2002

51- JHA V., GARCIA-GARCIA G., ISEKI K., LI Z., NAICKER S., PLATTNER B., et al.: "Chronic kidney disease: Global dimension and perspectives. The Lancet, 382 (9888): 260-272, 2013

52- LI J., CAMPANALE N.V., LIANG R.J., DEANE J.A., BERTRAM J.F. and RICARDO S.D.: Inhibition of p38 mitogen-activated protein kinase and transforming growth factor-beta1/Smad signaling pathways modulates the development of fibrosis in adriamycin-induced nephropathy. Am. J. Pathol., 169 (5): 1527-40, 2006.

53- LI Y., KANG Y.S., DAI C., KISS L.P., WEN X. and LIU Y.: Epithelial-to-mesenchymal transition is a potential pathway leading to podocyte dysfunction and proteinuria. Am. J. Pathol., 172: 299-308, 2008.

54- FLAQUER M., FRANQUESA M., VIDAL A., BOLAÑOS N., TORRAS J., LLOBERAS N., et al.: Hepatocyte growth factor gene therapy enhances infiltration of macrophages and may induce kidney repair in $\mathrm{db} / \mathrm{db}$ mice as a model of diabetes. Diabetologia., 55: 2059-2068, 2012.

55- ZOU M.S., JIAN Y.U., GUO-MING N.I.E., WEI-SUN H.E., LI-MAN L.U.O. and HONG-TAO X.U.: 25dihydroxyvitamin D3 decreases adriamycin-induced podocyte apoptosis and loss. Int. J. Med. Sci., 7 (5): 290299,2010

56- DAI C., SALEEM M.A., HOLZMAN L.B. MATHIESON P. and LIU Y.: Hepatocyte growth factor signaling ameliorates podocyte injury and proteinuria. Kidney Int., 77: 962-73, 2010

57- ZHANG L.F., CAO S.L., HUANG W.Z., WANG Y.G. and ZHU X.D.: Effects of shenshuning recipe on expression of hepatocyte growth factor in rats with glomerulosclerosis. Zhong Xi Yi Jie He Xue Bao, 4 (3): 289-92, 2006.

58- GOHDA E.: Function and regulation of production of hepatocyte growth factor (HGF).Nihon Yakurigaku Zasshi, 119 (5): 287-294, 2002.

59- KATO T., MIZUNO S. and NAKAMURA T.: Preservations of nephrin and synaptopodin by recombinant hepatocyte growth factor in podocytes for the attenuations of foot process injury and albuminuria in nephritic mice. Nephrology, 16: 310-318, 2011. 
60- MIZUNO S., MATSUMOTO K. and NAKAMURA T.: HGF, as a renotrophic and anti-fibrotic regulator in chronic renal disease. Front. Biosci., 13: 7072-7086, 2008.

61- GIANNOPOULOU M., DAI C., TAN X., WEN X., MICHALOPOULOS G.K. and LIU Y.: Hepatocyte growth factor exerts its anti-inflammatory action by disrupting nuclear factor-kappaB signaling. Am. J. Pathol., 173 (1): 30-41, 2008.

62- LIANG C.L., WU J.B., LAI J.M., YE S.F., LIN J., OUYANG H., et al.: Protection Effect of Zhen-Wu-Tang on Adriamycin-Induced Nephrotic Syndrome via Inhibiting Oxidative Lesions and Inflammation Damage. Evid Based Complement Alternat. Med., 131604, 2014.

63- TANNOCK L.: Dyslipidemia in Chronic Kidney Disease In: Feingold K.R., Anawalt B., Boyce A., et al., editors. Endotext [Internet]. South Dartmouth (MA): MDText.com Inc., 2000-Last Update: January 22, 2018.

64- ZOCCALI C., VANHOLDER R., MASSY Z.A., ORTIZ A., SARAFIDIS P., DEKKER FW., et al: The systemic nature of CKD. Nat. Rev . Nephrol., 13: 344-358, 2017.

65- OH Y.: The insulin-like growth factor system in chronic kidney disease: Pathophysiology and therapeutic opportunities. Kidney Res. Clin. Pract., 31: 26-37, 2012.

66- HIRSCHBERG R. and ADLER S.: Insulin-like growth factor system and the kidney: Physiology, pathophysiology, and therapeutic implications. Am. J. Kidney Dis., 31 (6): 901-919, 1998.

67- BERLANGA-ACOSTA J., GAVILONDO-COWLEY J., LÓPEZ-SAURA P., GONZÁLEZ-LÓPEZ T., CASTROSANTANA M.D., LÓPEZ-MOLA E., et al.: "Epidermal growth factor in clinical practice-a review of its biological actions, clinical indications and safety implications", International Wound Journal, 6 (5): 331-346, 2009.

68- GONG R., RIFAI A. and DWORKIN L.D.: Antiinflammatory effect of hepatocyte growth factor in chronic kidney disease: Targeting the inflamed vascular endothelium, J. Am. Soc. Nephrol., 17: 2464-2473, 2006.

69- LINDEN J.: Adenosine in tissue protection and tissue regeneration. Mol. Pharmacol., 67: 1385-1387, 2005.

70- SEKERCI C.A., TANIDIR Y., SENER T.E., SENER G., CEVIK O., YARAT A., et al.: Effects of platelet-rich plasma against experimental ischemia/reperfusion injury in rat testis. J. Pediatr.Urol., 13 (3): 317.e1-317.e9 , 2017.

71- TOHIDNEZHAD M., WRUCK C.J., SLOWIK A., KWEIDER N., BECKMANN R. and BAYER A., et al.: Role of Platelet-released growth factors in detoxification of reactive oxygen species in osteoblasts. Bone, 65: 9-17, 2014.

72- WU Y., DONG J., YUAN L., LIANG C., REN K., ZHANG W., FANG F. and SHEN J.: Nephrin and podocin loss is prevented by mycophenolate mofetil in early experimental diabetic nephropathy. Cytokine, 44: 85-91, 2008.

73- ZHU C., HUANG S., DING G., YUAN Y., CHEN Q., PAN X., et al.: Protective effects of Huang Qi Huai granules on Adriamycin nephrosis in rats Pediatr. Nephrol., 26: 905-913, 2011.

74- TONG S., LIU J., and ZHANG C.: Platelet-rich plasma inhibits inflammatory factors and represses rheumatoid fibroblast-like synoviocytes in rheumatoid arthritis. Clin. Exp. Med., 17 (4): 441-449, 2017.

75- BENDINELLI P., MATTEUCCI E., DOGLIOTTI G., CORSI M.M., BANFI G., MARONI P., et al.. Molecular basis of anti-inflammatory action of platelet-rich plasma on human chondrocytes: Mechanisms of NF-B inhibition via HGF. Journal of Cellular Physiology, 225 (3): $757-$ 766, 2010.

76- MOUSSA M., LAJEUNESSE D., HILAL G. EL ATAT O., HAYKAL G., SERHAL R., et al.: "Platelet rich plasma (PRP) induces chondroprotection via increasing autophagy, anti-inflammatory markers, and decreasing apoptosis in human osteoarthritic cartilage", Experimental Cell Research, 352 (1): 146-156, 2017.

77- MOU S., WANG Q., SHI B., GU L. and NI Z.: Hepatocyte Growth Factor Suppresses Transforming Growth FactorBeta- 1 and Type III Collagen in Human Primary Renal Fibroblasts. Kaohsiung J. Med. Sci., 25 (11): 577-587, 2009.

78- INSEL P.A., MURRAY F., YOKOYAMA U., ROMANO S., YUN H., BROWN L., et al.: cAMP and Epac in the regulation of tissue fibrosis, Br. J. Pharmacol., 166: 447$456,2012$.

79- SALEM N., HAMZAA A. and AYAZ H.A.: Biochemica and Molecular Mechanisms of Platelet-Rich Plasma in Ameliorating Liver Fibrosis Induced by Dimethylnitrosurea. Cell Physiol. Biochem., 47: 2331-2339, 2018. 


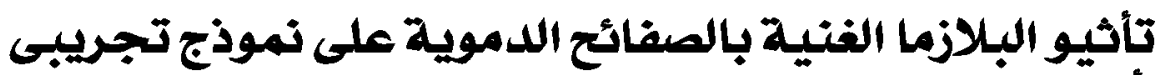

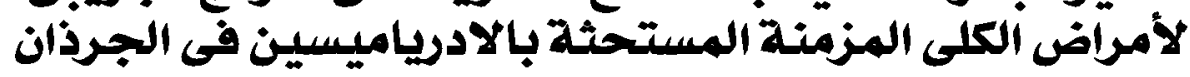

الهدف من الدراسة: تم تصميم هذه الدراسة الحالية لفحص تأثير العلاج بالبلازما الفنية بالصفائح الدموية على نموذج تجريبى لأمراض

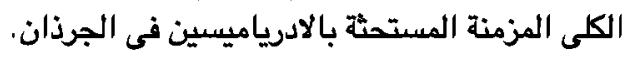

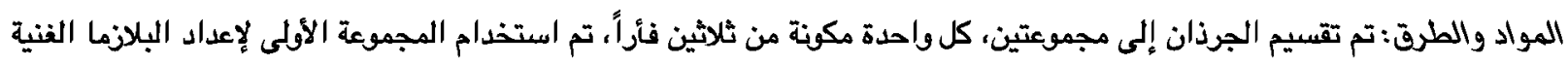

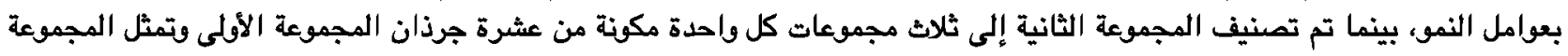

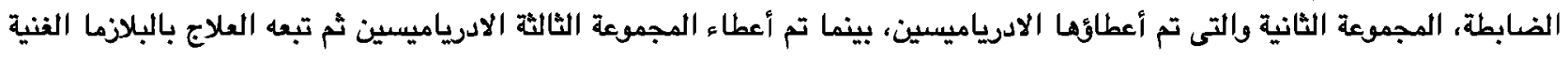

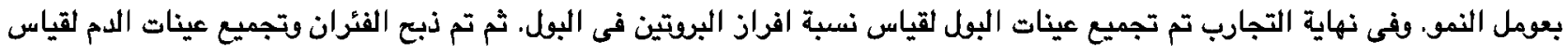

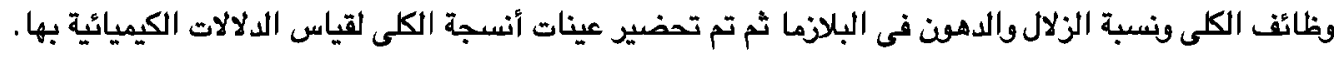

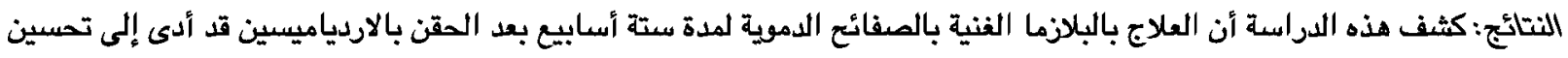

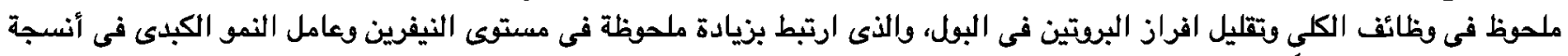

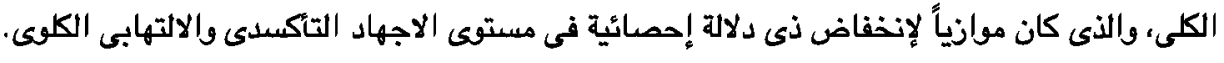

الخلاصة: هذه النتائج تشير إلى الأثار المفيدة العلاج بالبلازما الفنية بالصفائح الدموية على مرض الكلى المزمن المستحث بالاردياميسين 